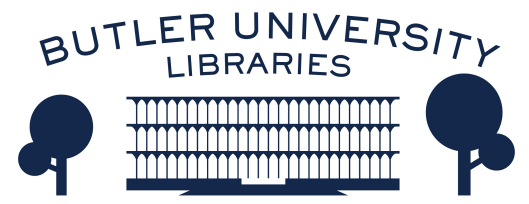

Journal of Hindu-Christian Studies

January 2008

\title{
Book Review: "The History of the Holy Servants of the Lord Siva: A Translation of the Periya Puranam of Cekkilar"
}

M. Thomas Thangaraj

Follow this and additional works at: https://digitalcommons.butler.edu/jhcs

Part of the Religion Commons

\section{Recommended Citation}

Thangaraj, M. Thomas (2008) "Book Review: "The History of the Holy Servants of the Lord Siva: A Translation of the Periya Puranam of Cekkilar"," Journal of Hindu-Christian Studies: Vol. 21, Article 22. Available at: https://doi.org/10.7825/2164-6279.1421

The Journal of Hindu-Christian Studies is a publication of the Society for Hindu-Christian Studies. The digital version is made available by Digital Commons @ Butler University. For questions about the Journal or the Society, please contact cbauman@butler.edu. For more information about Digital Commons @ Butler University, please contact digitalscholarship@butler.edu. 
University Press, 2001 [Winner of the Best Book in Hindu-Christian Studies prize for 20002002]). In the last chapter of Kerala Christian Sainthood, the author left us with a picture of herself overcome by grief at the apparently insurmountable barrier preventing full participation in an "other" religious community's most powerful rituals. She writes, "I felt as though I was watching a wonderful party from a distance but was not, in fact, invited to take part....In other words, I was stranded outside of something I understood to be profoundly rich but did not know how I could, ultimately, enter into it" (160). At the Rush temple, in contrast, these barriers to full participation appear to have been broken. Without losing her sense of belonging to the Roman Catholic tradition, Dempsey takes a mantra from Aiya, marking her initiation into the Srividya path. Moreover, Dempsey herself experiences the Goddess' grace in the form of extraordinary sensations brought forth by the temple's rituals.

In challenging scholarly conventions that seek to preserve scholarly objectivity by maintaining emotional distance from one's subject matter, Dempsey joins the company of recent anthropologists of religion like Meena Khandelwal and Loring Danforth, who practice a form of self-reflexive anthropology. The danger, of course, is that such intense selfreflexivity will collapse into the kind of academic navel-gazing aptly called "meresearch." In my view, Dempsey completely avoids that trap. Rather, her attention to her own and other people's complex emotional, physical and psychological responses to events and people provides an immensely valuable window into the dynamics of guru-seshya and community relationships so central to Hindu spiritual life.

Readers of this journal whose interest in religious encounters across the boundaries of tradition has taken them to the study of North American Hinduism will find much to appreciate in this book. A kind of symmetry exists between the work people must do to indigenize Christianity in a non-Western land (a prominent theme in Dempsey's previous book), and that required to transmit Hinduism in North America, with its predominately secular and Christian culture. I was somewhat disappointed not to see these parallels examined at greater length. Yet in The Goddess Lives in Upstate New York, the encounter between Christianity and Hinduism takes place more subtly, at the level of persons rather than abstract ideas or macro-level social processes. We see this, for example, when Dempsey's own formation as a Catholic with sympathies toward Liberation Theology gets challenged by the extravagance expenditures undertaken in the rituals honoring Sri Rajarajeshwari (pp. 16-22), and in Aiya's experiences of miraculous interventions by a canonized Catholic priest named Padre Pio, whose memory he still honors through the installation of his portrait in the temple office (pp. 188-190).

When Dempsey directly asks Aiya if there is an aspect of North American religions that he integrates into his own practice, he answers that it is the testimonial, "a personal story geared to empower and increase the faith of the listener" (p. 75). Dempsey follows suit: the book is a garland of stories, deftly connected to one another through analysis, comparison and thoughtful self-reflection. The result is a delightful study of diaspora Hinduism that will, at minimum, increase the reader's faith in the anthropology of religion.

Eliza F. Kent

Colgate University

\section{The History of the Holy Servants of the Lord Siva: A Translation of the Periya Puranam of Cekkilar. Alastair McGlashan. Victoria, B.C. Canada: Trafford Publishing, 2006, pp. xii +417.}

THE Saivite tradition of Tamil Nadu, India has had a long history of hymnic, philosophical, mythological, and hagiographic literature in Tamil language. In each of these literary 
traditions one can detect the dominance of poetic imagination. Here poetics is not limited to hymnic tradition alone; philosophical discussions are done through poetic discourse and so are the biographies of the sixty three saints of Tamil Saivism, called the Nayanmars. These saints made significant contributions to the maintenance and spread of Saivite faith during the time when Buddhist and Jain religious traditions were dominant in that part of the world. Periya Puranam of Cekkilar, who lived during the reign of the Chola king Kulottunka II (1133-1150), is one such epic poem on the sixty three Nayanmars.

Alastair McGlashan, in this volume, offers us an accurate, lucid, and readable translation of this magnum opus in exquisite English prose. McGlashan came to Tamil Nadu in the 1960s as an Anglican missionary and a theological teacher. But he was, within a brief period of time, able to master the Tamil language to such an extent that he wrote the first authoritative book on Greek Grammar in Tamil, introducing New Testament Greek to Tamil theological students. Even today his book on Greek grammar is widely used by Tamil students. One can easily recognize his mastery of Tamil in the lucid translation of this complex Tamil poetical epic.

In the opening pages of the book, McGlashan offers us an excellent and highly informative introduction to the tradition of Tamil Saivism. He begins with an outline of the historical background, moves on to a description of the religion of the Nayanmars and the literary character of Cekkilar's work, and ends with some guidelines as to how one should read this epic poem in today's context. McGlashan is keenly aware of the insurmountable distance in time between Cekkilar and the post-modern readers, and therefore provides helpful pointers to understand and appreciate traces of violence both in the language used and in the devotional acts of the Nayanmars. He concludes this section with the statement that Cekkilar "gives us a moving picture of the social and practical outworking of an exalted religious ideal, in which it would be hard for the adherent of any religious faith to deny the operation of divine grace and the moving of the divine spirit." (18) One is reminded of G. U. Pope, who, in presenting a metrical translation of Tiruvacagam (another Tamil Saivite classic) in 1900, expressed the same kind of sentiment with regard to the grace-filled spirituality of the saints of Tamil Saivism.

The translation contains 78 chapters organized under 13 sections, followed by notes and appendices. A helpful bibliography is given at the end. McGlashan has organized the chapters in such a way that the original format of the work is not distorted but presented in a way that offers the reader easy access to the text and greater facility with cross-referencing. The translation is faithful to the text not only in the literal sense but also in capturing the tone and ethos of the narratives. There are several photographic illustrations given throughout the book, which enable the reader to visualize the setting of the Nayanmars. The map of the Tamil Nadu of Cekkilar's time is very helpful in understanding the location of the hagiographic narratives. Perhaps a contemporary political map of Tamil Nadu by the side of this map might have been a greater help.

Periya Puranam is a great asset to any serious student of Tamil Saivism. McGlashan has, through this excellent translation, opened the doors for non-Tamil-speaking scholars to enter into the world of Tamil Saivite saints and experience the bhakti (devotion) of these saints. Even those who are encountering Tamil Saivism for the first time will be able to understand and enjoy this epic, thanks to McGlashan's highly informative introduction. It is truly admirable that he is able to offer this substantive and accessible introduction within the first eighteen pages of the book.

In offering this translation to the wider public, McGlashan has reminded us of the great tradition of Christian and Western scholars who were fascinated with and admired Hindu religious traditions. He rightly mentions at the end of his preface that he stands in the great tradition of Christians scholars such as Beschi, Caldwell, and Pope, and writes, "It remains for me only to lay the completed work, which has truly been a labour of love, at the lotus feet of the one Lord who rules over earth and heaven, by whatever name he is known." (x). One discovers in this work three important milestones in Hindu-Christian relations. First, 
this work forcefully reminds us that a helpful way to enter into the ethos of a religious tradition is through its narrative tradition. Hindus and Christians need to share with one another their respective hagiographies that offer multiple points of contact between the two traditions. Second, it affirms the fact that the religious heritage of every religion belongs to the jointly-owned wealth of the whole of humanity. Such a view opens people of all religions to access, enjoy, and be enhanced by Tamil Saivism. Once such common heritage is acknowledged, one is compelled to question any particular and narrowly defined religious identity as a requirement for the enjoyment of a particular religious tradition. Third, an easy access to Hindu religious tradition through works of this kind offers to all religionists especially Christians - a vision of the one "who rules over earth and heaven, by whatever name he is known."

M. Thomas Thangaraj

Emory University, Atlanta; GA.

\section{Bourgeois Hinduism, Or the Faith of the Modern Vedantists. Brian A. Hatcher. New York: Oxford University Press, 2008, 226 pp.}

"ON the evening of September 29, 1839, a small group of earnest young men met in a small room on the premises of the Tagore mansion in north Calcutta." This unassuming opening to Brian A. Hatcher's most recent work on religion in colonial Calcutta gives little indication that the book that follows, covering the origins and evolution of an almost-forgotten religious society, might compel us to reconsider the most commonly told story of the birth of modern, reformist Hinduism. Through his discovery, translation, and analysis of the founding discourses of the Tattvabodhini Sabha (TruthPropagating Society) and his reconstruction of the evolution of that group's major ideas, Hatcher has unsettled our understanding of the religious milieu of Calcutta in the period following the death of modern Hinduism's most famous architect, Rammohan Roy. Canonical history generally traces an uninterrupted development of neo-Vedanta that begins with Roy working out his insights in a climate of dialogue and debate with Islam, Unitarianism, and evangelical missionaries in Calcutta. Steady success led, this version goes, to the mid-century diffusion of reforming Hinduism. The most significant revision to our previous set of ideas about the emergence of modern Hinduism is this book's resituation of Roy himself. The book deals with Roy in only a single, preliminary chapter, as a deceased reformer whose institutional legacy, the Brahmo Samaj was languishing and straying from its founding principles until the Tattvabodhini Sabha and
Debendranath Tagore, its guiding force, later revived his memory as their founding inspiration considerably after the fact.

Hatcher characterizes the Tattvabodhini Sabha as an independent and initially more successful movement, born from the religious longing of Debendranath. His experience and spiritual quest were also characteristic of a class of men at the forefront of a commercial revolution that was taking place in Calcutta. This class, called bhadralok in Bengali, possessed or acquired the necessary connections and educations that enabled them to benefit from the expansion of the British Raj, some materially, some merely socially. And while many bhadralok were able also to convert their successes into concomitant markers of status recognized by both Hindu and British society, they seem to have experienced significant dislocation from traditional religion and society. The rationalist, monotheistic, scripturally anchored, morally rigorous, and anti-idolatrous faith of such groups as the Tattvabodhini Sabha and the Brahmo Samaj fulfilled those longings with a religious ideology perfectly suited to the social and intellectual circumstances of this new class.

Although the Brahmo Samaj (founded in 1828) preceded the Tattvabodhini Sabha by more than a decade, after Rammohan's death in England in 1833, the society fell into a period of relative obscurity and inactivity until the Tattvabodhini Sabha agreed to manage its affairs in 1843. In the preceding two or three years, 